\title{
BMJ Open A systematic review of associations between environmental exposures and development of asthma in children aged up to 9 years
}

\author{
S Dick, ${ }^{1}$ A Friend, ${ }^{2}$ K Dynes, ${ }^{2}$ F AlKandari, ${ }^{2}$ E Doust, ${ }^{3}$ H Cowie, ${ }^{3} \mathrm{~J}$ G Ayres,,${ }^{1,4}$ \\ S W Turner
}

To cite: Dick S, Friend A, Dynes K, et al. A systematic review of associations between environmental exposures and development of asthma in children aged up to 9 years. BMJ Open 2014;4:e006554. doi:10.1136/bmjopen-2014006554

- Prepublication history and additional material is available. To view please visit the journal (http://dx.doi.org/ 10.1136/bmjopen-2014006554).

Received 6 September 2014 Revised 9 October 2014 Accepted 22 October 2014

CrossMark

For numbered affiliations see end of article.

Correspondence to Dr S W Turner; s.w.turner@abdn.ac.uk

\section{ABSTRACT}

Objectives: Childhood asthma is a complex condition where many environmental factors are implicated in causation. The aim of this study was to complete a systematic review of the literature describing associations between environmental exposures and the development of asthma in young children.

Setting: A systematic review of the literature up to November 2013 was conducted using key words agreed by the research team. Abstracts were screened and potentially eligible papers reviewed. Papers describing associations between exposures and exacerbation of pre-existing asthma were not included. Papers were placed into the following predefined categories: secondhand smoke (SHS), inhaled chemicals, damp housing/mould, inhaled allergens, air pollution, domestic combustion, dietary exposures, respiratory virus infection and medications.

Participants: Children aged up to 9 years.

Primary outcomes: Diagnosed asthma and wheeze.

Results: 14691 abstracts were identified, 207 papers reviewed and 135 included in the present review of which 15 were systematic reviews, 6 were metaanalyses and 14 were intervention studies. There was consistent evidence linking exposures to SHS, inhaled chemicals, mould, ambient air pollutants, some deficiencies in maternal diet and respiratory viruses to an increased risk for asthma (OR typically increased by 1.5-2.0). There was less consistent evidence linking exposures to pets, breast feeding and infant dietary exposures to asthma risk, and although there were consistent associations between exposures to antibiotics and paracetamol in early life, these associations might reflect reverse causation. There was good evidence that exposures to house dust mites (in isolation) was not associated with asthma risk. Evidence from observational and intervention studies suggest that interactions between exposures were important to asthma causation, where the effect size was typically 1.5-3.0.

Conclusions: There are many publications reporting associations between environmental exposures and modest changes in risk for asthma in young children, and this review highlights the complex interactions between exposures that further increase risk.

\section{Strengths and limitations of this study}

- This is the first systematic review of the whole literature relating early life environmental exposures to childhood asthma causation.

- A high level of evidence was available (ie, systematic reviews, meta-analyses and/or intervention studies) for many exposure classes.

- More than $70 \%$ of papers identified described associations observed within single populations.

- The observational literature is likely to be affected by publication bias, reverse causation and confounders.

- Studies describing outcomes in children where the mean age was $>9$ years were not included.

\section{INTRODUCTION}

Asthma is a common chronic condition in children where environmental and genetic factors are implicated in causation. The rapid rise in asthma during the 1980s and $1990 \mathrm{~s}^{1}$ was too abrupt to be explained solely by change in prevalence of genetic variations. Changing environmental exposures appear to be relevant to the high prevalence of asthma in the Western world, ${ }^{2}$ although some exposures are likely to be effective via epigenetic mechanisms. ${ }^{3}$

Many environmental exposures have been linked to asthma causation, including allergens, ${ }^{4}$ smoking, ${ }^{5}$ dietary factors ${ }^{6}$ and respiratory infections. ${ }^{7}$ Recently, evidence has emerged to suggest that asthma causation may involve interactions between different environmental exposures ${ }^{8} 9$ and/or environmental exposures and atopy. ${ }^{10}$ Owing to the many challenges of relating even a single exposure to asthma causation, there is very little synthesis in the literature of multiple environmental exposures and asthma causation.

The Environmental Determinants of Public Health in Scotland (EDPHiS) was commissioned in 2009 to quantify the evidence on the connections between the environment and 
key aspects of health of children in order to inform the development of public policy. Asthma was identified as a priority along with obesity, unintentional injury and mental health. The overall aim of this systematic review was to capture all of the literature associating early environmental exposures and asthma development in children up to 9 years of age; this cut-off was chosen to avoid the effects of puberty and active smoking on asthma causation. A recent paper describes associations between environmental exposures and asthma control and exacerbation. ${ }^{11}$ Our specific aims were (1) to describe the magnitude of association between the development of asthma and environmental exposures and (2) to explore evidence of interactions between environmental exposures.

\section{METHODS}

\section{Study design}

A workshop attended by senior researchers from government and academia, and health practitioners and policy professionals identified environmental influences considered important on causation and exacerbation of asthma (previously described, ${ }^{11}$ box 1 ). By extrapolation from approaches to assessment of causation in workplace exposures for compensation purposes (http://iiac. independent.gov.uk/about/index.shtm), we considered an exposure that increased the risk for asthma by at least twofold as having at least a modest effect size.

\section{Search strategy and data sources}

The search strategy for MEDLINE is provided in the online supplementary material and has also been described previously. ${ }^{11}$ Two reviewers (SD and ED) searched the electronic databases (including MEDLINE, EMBASE, Cochrane controlled trials register (CCTR) and CINHAL) and reference lists of other studies and reviews between January 2010 and April 2010. Updated searches were carried out in July 2011 and November 2013. No date limits were applied to the search strategy.

Box 1 Areas for environmental determinants of causation and exacerbation of asthma derived from stakeholder workshop

- Environmental tobacco smoke (antenatal and postnatal);

Domestic combustion (cooking, heating and candles);

- Inhaled chemicals (volatile organic compounds, Chlorine, phthalates);

- Damp housing/mould;

Inhaled allergens (house dust mite, pets, pollens);

- Air pollution;

- Dietary exposures (maternal diet, breast feeding, diet in childhood);

- Respiratory virus infection;

- Medications (antibiotics and paracetamol);

- Industrial combustion (incinerators);

Fireworks and bonfires;

Vacuuming;

Air conditioning or humidifiers.
Studies identified from searching electronic databases were combined, duplicates removed and papers were screened for relevance to the review based on the information contained in the title and abstract. Abstracts were screened by a second reviewer (SWT) and potentially eligible papers were identified.

\section{Inclusion/exclusion criteria}

Studies were included if (A) they captured exposure to an environmental factor identified as potentially relevant to the development of asthma; (B) the mean age of asthma outcome was $\leq 9$ years. (C) Outcomes include diagnosis of asthma or data related to healthcare utilisation (hospital admissions, drug use), (D) the study design was either a meta-analysis, systematic review, randomised control trial, non-randomised control trial or cohort study. If no evidence was apparent for an exposure, then studies meeting the lower Scottish Intercollegiate Guidelines Network criteria were considered, that is, case-control and case report studies (http://www.sign.ac.uk/guidelines/fulltext/ 50/annexb.html 21 Jun 2014).

\section{Study selection and data extraction}

The full text of references identified as potentially relevant was obtained and papers included by applying the inclusion criteria, sometimes after discussion between reviewers (SD and SWT). Papers that were included in a systematic review were not included. For cohort studies where outcomes were reported at increasing ages after one exposure, only the most recent paper was included. A summary table included the following details from studies: study design, characteristics of the study population, study objectives and the key outcome(s) reported including what the primary asthma outcome was, for example, wheeze, physician diagnosed asthma, etc.

\section{Quality assessment}

Quality assessment of included papers was carried out using "Effective public health practice project quality assessment tool for quantitative studies" (http://www. ephpp.ca/PDF/Quality\%20Assessment\%20Tool_2010_2. pdf accessed Jun 2014). Results are presented in the online supplementary material; due to the relatively large number of studies identified, a random $10 \%$ were chosen for quality assessment.

\section{RESULTS}

\section{Literature search}

There were 14691 references identified from electronic databases and other studies. There were 207 full papers reviewed and 135 studies met the inclusion criteria (figure 1). There were 15 systematic reviews, 6 meta-analyses, 92 cohort studies, 14 intervention studies included, 5 case-control studies and 3 cross-sectional studies. No case series were included. There were 62 studies from Europe (including 3 meta-analyses), 32 from North America, 13 studies from Australia or New 
Citations identified from searches $(n=14691)$

Abstracts excluded due to wrong topic - including papers concerning asthma exacerbations $(n=14484)$

Potentially relevant abstracts identified and full text screened for inclusion criteria $(n=207)$

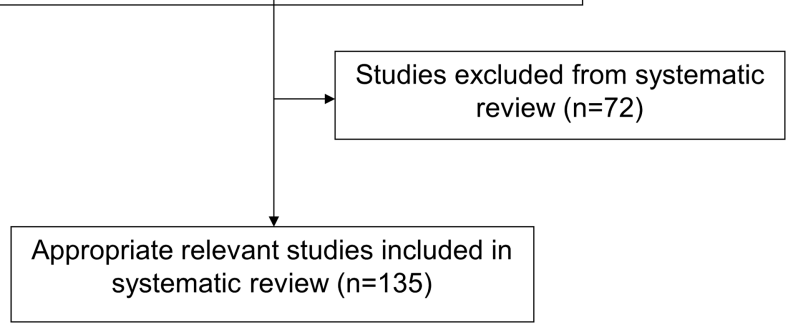

Figure 1 QUOROM statement flow chart.

Zealand, 3 from Japan and single remaining papers from UAE, India, Qatar, South Korea, Mexico, Taiwan and Brazil. There were $84(63 \%)$ studies published in the past 5 years, that is, from 2009. Box 1 in the online supplementary file presents details of the included studies, including number and mean age of children included, the respiratory outcome reported and the effect size. No studies were identified for industrial combustion, fireworks, bonfires, vacuuming, air conditioning or air humidifiers. Table 1 presents the effect size of the exposures on asthma risk from the studies identified. Table 2 presents results from studies where interactions between exposures were associated with altered asthma risk

\section{Secondhand smoke}

\section{Antenatal exposure}

One meta-analysis and five cohort studies were identified and most found exposure was associated with increased risk for asthma. The meta-analysis ${ }^{12}$ identified 735 exposed children and concluded that exposure was associated with an increased risk for asthma at 6 years (OR 1.7). The cohort studies found that risk was increased by $1.13^{13}$ and $2.1^{14}$ at 2 years, and 1.4 at 7 years. ${ }^{15}$ One study of infants born 3-4 weeks prematurely found increased risk for wheeze at 3 years only among those exposed to secondhand smoke (SHS; OR 4.0, table 2). ${ }^{16}$ One study found no association between antenatal exposure and risk for symptoms. ${ }^{17}$

\section{Postnatal exposure}

One systematic review and six cohort studies were identified and all reported that exposure was associated with increased asthma risk. The systematic review concluded that exposure to tobacco smoke was associated with an increased risk of 1.3 among children aged 6-18 years. ${ }^{5}$ Postnatal exposure was associated with increased risk for wheeze between $1.2^{18}$ and $2.9,{ }^{17}$ and 1.7 for asthma at 5 years (table 2). ${ }^{19}$ The study from Japan ${ }^{17}$ found a link between postnatal but not antenatal maternal smoking and wheeze at $16-24$ months. One study ${ }^{18}$ found that postnatal paternal smoking was a risk factor for wheeze (RR 1.14 (1.04 to 1.24)) independent of maternal smoking. Another study reported an interaction between short duration of maternal education and SHS exposure. ${ }^{19}$ A final study found that increasing exposure to fine particulates $\left(\mathrm{PM}_{2.5}\right)$ and urinary cotinine, products of tobacco combustion, was positively linked to risk for infant wheeze. ${ }^{20}$

\section{Domestic combustion}

Two cohort, one cross-sectional and two case-control studies were identified and there was inconsistent evidence between exposure and asthma risk. One cohort study retrospectively modelled exposure to gas cooking at 5 years to asthma in 4-year-olds and found no association. ${ }^{21}$ In a second cohort study, increasing exposure to domestic $\mathrm{PM}_{2.5}$ was associated with increased risk for new onset wheeze over the next 3 years (OR 1.5 per quartile increase in exposure), adjusting for SHS exposure. $^{22}$ A cross-sectional study found an association between detectable indoor air sulfur dioxide $\left(\mathrm{SO}_{2}\right)$ and risk for wheeze (OR 1.8) at age 6-10 years. ${ }^{23}$ This study found no link between burning incense and asthma symptoms $^{23}$ and this was consistent with a case-control study that found no evidence for exposure to Bakhour incense and risk for asthma. ${ }^{24}$ A case-control study from India $^{25}$ found evidence for increased asthma among children (OR 4.3) living in homes where biomass was used for cooking compared with other homes.

\section{Inhaled chemicals}

One meta-analysis, one cohort study, one cross-sectional study and two reports from one case-control study were identified and all found evidence of exposure being associated with increased asthma risk. The meta-analysis of data from seven studies concluded that increasing formaldehyde exposure was associated with increased asthma risk (OR 1.2 per $10 \mu \mathrm{g} / \mathrm{m}^{3}$ increase). ${ }^{26}$ A cohort study $^{27}$ used redecoration of the apartment as a proxy for exposure to volatile organic compounds (VOCs) and found an increase in risk for obstructive bronchitis (OR 4.2). Simultaneous exposure to SHS and cats added to the risk of obstructive bronchiolitis in the second year (OR 5.1, table 2). ${ }^{27}$ One cross-sectional study ${ }^{28}$ found an association between indoor exposure VOC of microbial origin (MVOCs) and plasticisers, and risk of asthma (mean increased risk for asthma $2.1 / \mu \mathrm{g} / \mathrm{m}^{3}$ of total MVOC). Two scientific papers on the same study ${ }^{29} 30$ found domestic exposure to formaldehyde, benzene and its compounds, and toluene, was positively associated with asthma risk $\left(3 \%\right.$ increase per $10 \mu \mathrm{g} / \mathrm{m}^{3}$ increase in formaldehyde exposure). 
Table 1 Magnitude of effect of environmental exposure on respiratory symptoms

\begin{tabular}{|c|c|}
\hline Exposure & Magnitude of effect $(95 \% \mathrm{Cl})$ \\
\hline \multicolumn{2}{|l|}{ SHS } \\
\hline \multirow[t]{6}{*}{ Antenatal exposure } & $1.7(1.2$ to 2.3$) \ddagger^{12}$ \\
\hline & $1.13(1.04 \text { to } 1.23)^{* 13}$ \\
\hline & $2.1(1.2$ to 3.7$) \dagger^{14}$ \\
\hline & $1.35(1.13$ to 1.62$) \dagger^{15}$ \\
\hline & $4.0(1.9 \text { to } 8.6)^{* 16}$ \\
\hline & No association ${ }^{17}$ \\
\hline \multirow{5}{*}{ Postnatal exposure } & $1.3(1.1$ to 1.6$) \dagger \ddagger^{5}$ \\
\hline & $1.2(1.0 \text { to } 1.3)^{* 18}$ \\
\hline & $2.9(1.1 \text { to } 7.2)^{* 17}$ \\
\hline & $1.7(1.1$ to 2.58$) \dagger^{19}$ \\
\hline & $4.2(1.4,13.0)$ for exposure to high fine particulate ${ }^{* 20}$ \\
\hline \multicolumn{2}{|l|}{ Domestic combustion } \\
\hline Gas cooking & No association ${ }^{21}$ \\
\hline Fine particulates $\left(\mathrm{PM}_{2.5}\right)$ & 1.5 (1.1 to 2.2$)$ per quartile $\mathrm{PM}_{2.5}$ increase ${ }^{\star 22}$ \\
\hline Detectable Sulfur Dioxide & OR $1.8(1.1 \text { to } 3.1)^{\star 23}$ \\
\hline Incense & No association ${ }^{24} 17^{23}$ \\
\hline Biomass & $4.3(3.0$ to 5.0$) \dagger^{25}$ \\
\hline \multicolumn{2}{|l|}{ Inhaled chemicals } \\
\hline \multirow[t]{5}{*}{ VOC } & $1.2(1.01$ to 1.4$)$ per $10 \mu \mathrm{g} / \mathrm{m}^{3}$ increase $^{26}$ \\
\hline & $4.2(1.4$ to 12.9$) \eta^{27}$ \\
\hline & 2.1 (1.1 to 3.9$)$ per $\mu \mathrm{g} / \mathrm{m}^{3}$ of total $\mathrm{MVOC}^{* 28}$ \\
\hline & 1.39 (no Cl given) $\dagger^{29}$ \\
\hline & $2.92(2.25$ to 3.75$) \dagger^{30}$ \\
\hline \multirow[t]{2}{*}{ Chlorinated swimming pools } & $0.5(0.3$ to 0.9$) \dagger^{31}$ \\
\hline & No association $¥^{32}$ \\
\hline \multirow[t]{6}{*}{ Other chemicals } & $1.7(1.2 \text { to } 2.4)^{\star 34}$ (cleaning agents) \\
\hline & $1.6(1.2$ to 2.1$) \dagger \ddagger^{33}$ (PVC) \\
\hline & $1.9(1.1$ to 3.2$) \dagger^{35}$ (pyrene) \\
\hline & $0.7(0.5 \text { to } 0.9)^{* 36}$ (maternal BPA) \\
\hline & $1.4(1.0 \text { to } 1.9)^{* 36}$ (child BPA) \\
\hline & $2.8(2.0$ to 3.9$) \dagger^{37}$ and $1.7(1.01 \text { to } 2.9)^{\star 38}$ (oil refinery) \\
\hline \multirow[t]{6}{*}{ Damp housing/mould } & $1.5(1.3$ to 1.7$) \dagger \ddagger^{39}$ \\
\hline & $1.4(1.1$ to 1.8$))^{*} \ddagger^{40}$ (no association at $6-8$ years) \\
\hline & $7.1(2.2$ to 12.6$) \dagger^{41}$ \\
\hline & $2.4(1.1$ to 5.6$) \dagger^{42}$ for exposure \\
\hline & $2.6(1.1 \text { to } 6.3)^{43}$ per unit increase in mould index \\
\hline & $1.8(1.5 \text { to } 22)^{44}$ per unit increase in mould index \\
\hline \multirow[t]{8}{*}{ Multiple exposures } & $0.7(0.5$ to 0.9$) \ddagger^{48}$ \\
\hline & $0.4(0.3$ to 0.8$) \ddagger^{49}$ \\
\hline & $3.0(1.1$ to 7.9$)$ for high HDM + and $1.2(1.1 \text { to } 1.4)^{\star}$ per quartile LPS increase ${ }^{50}$ \\
\hline & $\begin{array}{l}1.8(1.02 \text { to } 3.0)^{\star} \text { increasing cockroach allergen }{ }^{55} \text { and } 0.3(0.1 \text { to } 0.98)^{\star} \text { for dog and } 0.6 \\
(0.4 \text { to } 1.01)^{\star} \text { for cat exposure } 55\end{array}$ \\
\hline & $2.6(1.3$ to 5.4$) \dagger$ for high cat exposure ${ }^{51}$ \\
\hline & $2.7(1.1$ to 7.1$) \dagger$ dog and SHS to $4.8(1.1$ to 21.5$) \dagger$ dog and elevated $\mathrm{NO}_{2}{ }^{56}$ \\
\hline & $3.1(1.8,5.2)^{*}$ for exposure to SHS, infection and no breast feeding ${ }^{57}$ \\
\hline & No association $\ddagger^{45} \ddagger^{46} \ddagger^{47} 52-54$ \\
\hline \multicolumn{2}{|l|}{ Inhaled allergens/particles } \\
\hline \multirow[t]{7}{*}{ Pet } & $0.7(0.6$ to 0.9$) \dagger \ddagger$ cat exposure ${ }^{59}$ \\
\hline & $1.1(1.0$ to 1.3$) \dagger \ddagger$ dog exposure ${ }^{59}$ \\
\hline & $4.7(1.2$ to 18.0$) \dagger$ cat exposure ${ }^{61}$ \\
\hline & $0.6(0.4 \text { to } 0.9)^{*}$ cat exposure ${ }^{62}$ \\
\hline & $0.3(0.1 \text { to } 0.81)^{\star}$ cat exposure ${ }^{63}$ \\
\hline & $1.2(1.1 \text { to } 1.3)^{\star}$ cat exposure ${ }^{64}$ \\
\hline & No association $\ddagger^{60} 6566$ \\
\hline \multirow[t]{2}{*}{ Other exposures } & $1.5{\text { (1.1 to } 2.1)^{*} \text { highest vs lowest quartile LPS exposure }}^{68}$ \\
\hline & $1.4(1.1 \text { to } 1.7)^{\star}$ mouse allergen ${ }^{69}$ \\
\hline
\end{tabular}


Table 1 Continued

\begin{tabular}{|c|c|}
\hline Exposure & Magnitude of effect $(95 \% \mathrm{Cl})$ \\
\hline & $0.4(0.2$ to 0.6$) \dagger$ feather quilt $^{70}$ \\
\hline & $1.8(1.0$ to 3.2$) \dagger$ number of synthetic bedding items ${ }^{71}$ \\
\hline & No association cockroach ${ }^{52}$ \\
\hline HDM & No association $\ddagger^{72} \ddagger^{7374}$ \\
\hline \multirow[t]{2}{*}{ Outdoor allergens } & $\begin{array}{l}\text { OR } 3.1(1.3 \text { to } 7.4)^{\star} \text { birthday during fungal spore season }{ }^{75} \text { OR } 1.4(1.1 \text { to } 1.7) \dagger \text { grass } \\
\text { pollen exposure }\end{array}$ \\
\hline & RR $1.2(1.02$ to 1.3$) \dagger$ tree canopy cover $^{77}$ \\
\hline \multirow[t]{11}{*}{ Air pollution } & $1.05(1.00$ to 1.11$) \dagger \ddagger$ per ppm increased $\mathrm{NO}_{2}{ }^{78}$ \\
\hline & 1.02 (1.00 to 1.04$) \dagger \ddagger$ per ppm increased $\mathrm{NO}^{78}$ \\
\hline & 1.06 (1.01 to 1.12$) \dagger \ddagger$ per ppm increased $\mathrm{CO}^{78}$ \\
\hline & $1.04(1.01 \text { to } 1.07)^{\star} \ddagger$ per ppm increased $\mathrm{SO}_{2}{ }^{78}$ \\
\hline & $1.05(1.04 \text { to } 1.07)^{\star} \ddagger$ per unit increase particulates ${ }^{78}$ \\
\hline & $1.04(1.01 \text { to } 1.07)^{\star}$ per ppm increased $\mathrm{CO}^{79}$ \\
\hline & $1.2(1.0$ to 1.31$) \dagger$ per $5 p p b$ increase $\mathrm{NO}_{2}{ }^{80}$ \\
\hline & $2.0(1.2$ to 3.6$) \dagger$ traffic-related particles ${ }^{82}$ \\
\hline & $1.3(1.0$ to 1.6$) \dagger$ higher traffic density ${ }^{84}$ \\
\hline & 3.1 (1.3 to 7.4$) \dagger$ high exposure to $\mathrm{PM}_{2.5}{ }^{85}$ \\
\hline & No association ${ }^{81}$ \\
\hline \multicolumn{2}{|l|}{ Dietary exposures } \\
\hline \multirow{6}{*}{$\begin{array}{l}\text { Maternal dietary components } \\
\text { during pregnancy }\end{array}$} & 0.2 (0.08 to 0.6$) \dagger \ddagger$ Mediterranean $\operatorname{diet}^{86}$ \\
\hline & $0.6(0.4 \text { to } 1.0)^{*}$ Western $\operatorname{diet}^{88}$ \\
\hline & $0.6,(0.3 \text { to } 0.96)^{*}$ fish consumption ${ }^{89}$ \\
\hline & $0.8(0.7$ to 1.0$)$ peanuts and $0.8(0.7$ to 0.8$)$ tree nuts $\dagger^{90}$ \\
\hline & 1.6 (1.2 to 2.0 ) low vegetables 1.5 (1.2 to 1.8$)$ low fruit and chocolate 1.4 (1.1 to 1.7$) \dagger^{91}$ \\
\hline & No association fish oil ${ }^{87} \ddagger$, butter and margarine ${ }^{92}$ \\
\hline \multirow{5}{*}{$\begin{array}{l}\text { Specific nutrient intake during } \\
\text { pregnancy }\end{array}$} & $0.6(0.4 \text { to } 0.7)^{\star} \ddagger$ increased vitamin D intake 86 \\
\hline & $0.7(0.5 \text { to } 0.9)^{*} \ddagger$ increased vitamin $E$ intake ${ }^{86}$ \\
\hline & $0.3(0.1 \text { to } 0.4)^{\star} \ddagger$ increased plasma vitamin $A^{86}$ \\
\hline & $0.95(0.91 \text { to } 0.99)^{*}$ per $10 \mathrm{nmol} / \mathrm{L}$ increase cord vitamin $\mathrm{D}^{97}$ \\
\hline & $\begin{array}{l}\text { No association vitamin } D(\text { plasma })^{93-95}{\text { (intake })^{96} \text {, dietary antioxidants }}^{99} \text { or folate }{ }^{100} \text { or } \\
\text { vitamin } A^{101} \text { supplements }\end{array}$ \\
\hline \multirow[t]{6}{*}{ Breast feeding } & OR $0.92(0.86 \text { to } 0.98)^{\star} \ddagger^{102}$ \\
\hline & OR 1.1 (1.0 to 1.2$) \dagger \ddagger^{102}$ \\
\hline & $1.4(1.2 \text { to } 1.7)^{\star}$ never breast feeding ${ }^{103}$ \\
\hline & 0.9 (0.8 to 0.96$) \dagger$ exclusive breast feeding ${ }^{104}$ \\
\hline & 2.0 (1.0 to 3.8$) \dagger$ maternal margarine intake during lactation ${ }^{98}$ \\
\hline & No association $\ddagger^{105}$ \\
\hline \multirow[t]{3}{*}{ Cow's milk formula } & RR $0.4,(0.2 \text { to } 0.9)^{*} \ddagger$ hydrolysed vs standard ${ }^{106}$ \\
\hline & OR $0.3(0.1 \text { to } 1.0)^{*}$ fatty acid supplementation ${ }^{108}$ \\
\hline & No association ${ }^{109}$ \\
\hline \multirow[t]{3}{*}{ Infant diet } & $0.4(0.2$ to 0.9$)$ for youngest vs oldest age at introduction of wheat $\dagger^{111}$ \\
\hline & $0.6(0.4$ to 0.9$)$ for early vs delayed introduction of fish ${ }^{115}$ \\
\hline & $\begin{array}{l}\text { No association with age at introduction of solids }{ }^{112113} \text { prebiotic supplementation } \ddagger^{117} \\
\ddagger^{118} \text { or vitamin supplementation }\end{array}$ \\
\hline \multirow[t]{5}{*}{ Child diet } & $0.6(0.4$ to 0.9$) \dagger$ full cream milk ${ }^{121}$ \\
\hline & 1.5 (1.04 to 2.1$)$ Western $\operatorname{diet}^{124}$ \\
\hline & $0.93(0.85$ to 1.00$)$ per fruit item consumption/day/week ${ }^{125}$ \\
\hline & $0.5(0.3$ to 0.6$)$ for highest vs lowest tertile plasma vitamin $D^{126}$ \\
\hline & No association milk supplementation $\ddagger^{120}$, organic food ${ }^{122}$, dietary anti oxidant ${ }^{123}$ \\
\hline \multicolumn{2}{|l|}{ Respiratory virus infection } \\
\hline \multirow[t]{6}{*}{ Respiratory infection \pm wheeze } & $0.5(0.3$ to 0.9$) \dagger$ for infant lower respiratory tract infection ${ }^{127}$ \\
\hline & $9.8(4.3 \text { to } 22.0)^{*}$ wheeze with rhinovirus ${ }^{128}$ \\
\hline & $2.9(1.2$ to 7.1$) \dagger$ wheeze with rhinovirus ${ }^{129}$ \\
\hline & 2.2 (1.5 to 3.3)† RSV infection $6-11$ months previously ${ }^{130}$ \\
\hline & $0.9(0.7$ to 1.0$) \dagger$ early day care ${ }^{132}$ \\
\hline & No association early day care ${ }^{131}$ \\
\hline
\end{tabular}


Table 1 Continued

\begin{tabular}{|c|c|}
\hline Exposure & Magnitude of effect $(95 \% \mathrm{Cl})$ \\
\hline \multicolumn{2}{|l|}{ Medications } \\
\hline \multirow[t]{3}{*}{ Antibiotics } & $1.2(1.0$ to 1.5$) \dagger \ddagger$ antenatal exposure ${ }^{135}$ \\
\hline & 1.5 (1.3 to 1.8$) \dagger \ddagger$ postnatal exposure ${ }^{135}$ \\
\hline & No association $\ddagger^{136}$ \\
\hline \multirow[t]{3}{*}{ Paracetamol } & $1.3(1.1$ to 1.4$) \dagger \ddagger^{139}$ \\
\hline & $1.2(1.0 \text { to } 1.4)^{\star} \ddagger^{138}$ \\
\hline & No association ${ }^{140}$ \\
\hline Other medications & $\begin{array}{l}1.1 \text { (1.0 to } 1.2) \text { for antibiotics, } 1.3(1.1 \text { to } 1.6) \text { gastro-oesophageal reflux treatment, } 1.6 \\
\text { (1.1 to } 2.3) \text { opiates, } 1.3(1.2 \text { to } 1.4) \text { thyroid supplements }\end{array}$ \\
\hline \multirow{5}{*}{$\begin{array}{l}\text { Other maternal exposures during } \\
\text { pregnancy }\end{array}$} & $2.7(1.2 \text { to } 6.0)^{\star}$ dietary dioxins and polychlorinated biphenyl ${ }^{141}$ \\
\hline & $2.3(1.3 \text { to } 4.1)^{*}$ highest vs lowest BPA exposure ${ }^{142}$ \\
\hline & $0.7(0.5 \text { to } 0.9)^{*}$ BPA exposure ${ }^{36}$ \\
\hline & $1.1(1.0 \text { to } 1.2)^{\star}$ per $10 \%$ increase in DDT metabolite ${ }^{143}$ \\
\hline & 1.2 (1.0 to 1.3) for increasing electromagnetic exposure ${ }^{144}$ \\
\hline \multicolumn{2}{|c|}{ 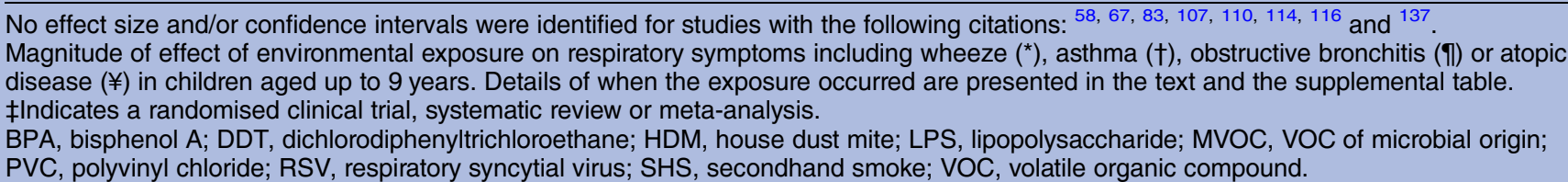 } \\
\hline
\end{tabular}

\section{Chlorinated swimming pools}

Two cohort studies were identified. Exposure to chlorinated swimming pools in infancy and childhood was associated with reduced risk for current asthma at 7 years (OR 0.5). ${ }^{31}$ A second study found no link between exposure to chlorine through swimming and asthma at 6 years of age $;^{32}$ those who did not attend swimming during the first year of life were more likely to have asthma.

\section{Other chemicals}

In this broad category, there was one systematic review, two cohort studies, two cross-sectional studies and a casecontrol study; all found evidence of exposures being linked to increased asthma symptoms. A systematic review of seven studies of children aged up to 12 years found a positive association between polyvinyl chloride exposure in dust samples and asthma (OR 1.6) ${ }^{33}$ One study (using the same cohort aforementioned ${ }^{31}$ ) created a composite household chemicals exposure score (including chlorine/chloride exposure), and found a positive association between exposure and risk of incident wheeze after 2.5 years of age (OR 1.7). ${ }^{34}$ Two cohort studies related antenatal and current exposures to asthma risk: high exposure to pyrene was associated with increased asthma risk in 5-6-year-olds (OR 1.9), ${ }^{35}$ and this association was only apparent in non-atopic children, and maternal exposure during pregnancy was not related to asthma (table 2); maternal bisphenol A (BPA) exposure during pregnancy was inversely associated with wheeze at 5 years (OR 0.7) but not at 7 years; however, the child's current exposure was positively associated with this outcome (OR 1.4). ${ }^{36}$ Living close to a petrochemical plant was associated with an increased risk for asthma (OR 2.8). ${ }^{37}$ A case-control study found increased wheeze in 6-14-year-olds living close to an oil refinery compared with controls (OR 1.7). ${ }^{38}$

\section{Damp housing/mould}

One systematic review, one meta-analysis plus four cohort studies were identified and early exposure was consistently associated with increased risk for later asthma symptoms. The systematic review included data from 16 studies and concluded that exposure to visible mould was associated with increased risk for asthma (OR 1.5). ${ }^{39}$ The meta-analysis of eight European birth cohorts found an association between exposure to visible mould or dampness and increased wheeze at 2 years (OR 1.4) but this was not significant at $6-8$ years (OR 1.1) ${ }^{40}$ The cohort studies found mould exposure in early life to be associated with increased risk for asthma at 3 years $(\mathrm{OR} 7.1)^{41}$ and 7 years (RR 2.4 for presence of any mould, ${ }^{42}$ and OR of $2.6^{43}$ and $1.8^{44}$ per unit increase in mouldiness index).

\section{Inhaled allergens}

\section{Indoor exposures}

Multiple exposures: There were five intervention studies and eight cohort studies identified. One intervention randomised newborns to house dust mite (HDM) reduction measures, avoidance of cow's milk or both or neither and found no difference in asthma incidence at age 5 years across the four groups. ${ }^{45}$ A second study also modified postnatal exposure to cow's milk protein (and other dietary allergens) and HDM and the intervention group had trends for reduced wheeze (OR 0.4 (0.2 to 1.08)) at 8 years. ${ }^{46}$ A third intervention study reduced exposures to SHS, inhaled and ingested allergens and promoted breast feeding but found no difference in asthma outcome age 6 years. ${ }^{47}$ The fourth intervention modified exposures to antenatal and postnatal oily fish, 
Table 2 Magnitude of effect of main effect on asthma aetiology and magnitude of interaction with other factor

\begin{tabular}{|c|c|c|}
\hline Study & Interaction between & Magnitude of interaction $(95 \% \mathrm{CI})$ \\
\hline Robison et al ${ }^{16}$ & $\begin{array}{l}\text { Late premature delivery (<37 weeks) } \\
\text { and antenatal SHS exposure }\end{array}$ & $\begin{array}{l}\text { OR for wheeze } 2.0 \text { ( } 1.3 \text { to } 3.1 \text { ) associated with prematurity and } 1.1 \\
(0.5 \text { to } 2.4) \text { with in utero SHS exposure. OR for wheeze } 3.8 \text { ( } 1.8 \text { to } \\
\text { 8.0) if both premature and SHS exposed }\end{array}$ \\
\hline Martinez et $a l^{19}$ & Smoke exposure from mother & $\begin{array}{l}\text { OR } 2.6 \text { ( } 1.4 \text { to } 4.6) \text { if exposed and mother } \leq 12 \text { years education } \\
\text { OR } 1.7 \text { ( } 1.1 \text { to } 2.6) \text { for asthma by } 5 \text { years }\end{array}$ \\
\hline Diez et $a R^{77}$ & $\begin{array}{l}\text { Redecoration } \\
\text { Pet exposure } \\
\text { Dampness }\end{array}$ & $\begin{array}{l}\text { Redecoration associated with OR for obstructive bronchiolitis at } \\
2 \text { years } 4.1(1.4 \text { to } 12.9) \text {. OR } 5.1 \text { (1.6 to 15.6) if also exposed to } \\
\text { ETS or pets }\end{array}$ \\
\hline Jung et $a \AA^{35}$ & $\begin{array}{l}\text { Pyrene exposure } \\
\text { Atopy }\end{array}$ & $\begin{array}{l}\text { High exposure was associated with increased risk for asthma } 1.9 \\
(1.1 \text { to } 3.2) \text { and this was increased to } 2.9 \text { (1.8 to 5.7) among } \\
\text { non-atopic children }\end{array}$ \\
\hline Carlsten et $a^{{ }^{6}}$ & $\begin{array}{l}\text { Dog exposure } \\
\text { SHS } \\
\text { High } \mathrm{NO}_{2}\end{array}$ & $\begin{array}{l}\text { No association with dog exposure per se } \\
\text { OR } 2.7(1.1 \text { to } 7.1) \text { for dog and } \mathrm{SHS} \\
\text { OR } 4.8 \text { ( } 1.1 \text { to } 21.5 \text { ) for dog plus high } \mathrm{NO}_{2}\end{array}$ \\
\hline Karmus et $a^{57}$ & $\begin{array}{l}\text { Recurrent lower respiratory tract } \\
\text { infection } \\
\text { Breast feeding } \\
\text { SHS }\end{array}$ & $\begin{array}{l}\text { OR } 2.5 \text { ( } 1.8 \text { to } 3.4 \text { ) for asthma at ages } 4 \text { and } 10 \text { years. OR } 3.1 \text { (1.8 } \\
\text { to } 5.2 \text { ) with antenatal exposure to products of tobacco smoke }\end{array}$ \\
\hline Melen et $a^{{ }^{1}}$ & $\begin{array}{l}\text { Smoke exposure } \\
\text { Pets } \\
\text { Window pane condensation }\end{array}$ & $\begin{array}{l}\text { OR for } 1 \text { to } 2 \text { and } 3 \text { exposures (compared to none) were } 1.1,4.4 \\
(1.0 \text { to } 18.6) \text { and } 10.8 \text { (2.0 to 59.6) }\end{array}$ \\
\hline Celedon et $a^{{ }^{2}}$ & $\begin{array}{l}\text { Early cat exposure } \\
\text { Maternal asthma }\end{array}$ & $\begin{array}{l}\text { Exposure associated with reduced risk for wheeze (OR } 0.6 \text { (0.4 to } \\
0.9) \text { ) but only in those with no maternal asthma }\end{array}$ \\
\hline Trevillian et $a l^{p 1}$ & $\begin{array}{l}\text { Synthetic bedding } \\
\text { Bedroom heating } \\
\text { Recent bedroom painting }\end{array}$ & $\begin{array}{l}\text { Exposure to }>1 \text { synthetic item of bedding was associated with } \\
\text { increased asthma (OR } 1.8(1.0 \text { to } 3.2) \text { ). Co-exposure to room } \\
\text { heating was associated with OR } 7.1(0.1 \text { to } 23.9) \text {, recent painting } \\
\text { OR } 7.2 \text { (2.3 to } 23.2)\end{array}$ \\
\hline Kim et $a \beta^{\beta 1}$ & $\begin{array}{l}\text { Ambient air pollution (ozone, } \mathrm{CO}, \\
\mathrm{NO}_{2}, \mathrm{SO}_{2} \text { and } \mathrm{PM}_{10} \text { ) } \\
\text { Previous bronchiolitis }\end{array}$ & $\begin{array}{l}\text { Asthma at } 5 \text { years not associated with higher exposures but among } \\
\text { bronchiolitis subset ozone exposure associated with OR } 7.5 \text { (2.7 to } \\
21.3), \mathrm{CO} \text { exposure OR } 8.3(2.9 \text { to } 23.7) \text { and } \mathrm{NO}_{2} \text { exposure OR } \\
7.9(0.97 \text { to } 64.8)\end{array}$ \\
\hline Ryan et $a^{\beta 2}$ & $\begin{array}{l}\text { Traffic-related particles (elemental } \\
\text { carbon attributable to traffic) } \\
\text { Domestic LPS }\end{array}$ & $\begin{array}{l}\text { A positive asthma predictive index at } 36 \text { months was associated } \\
\text { with exposure to increased levels of particles before } 12 \text { months } \\
(\mathrm{OR}=2.0(1.2 \text { to } 3.6)) \text {. Co-exposure to high concentrations of } \\
\text { endotoxin increased the risk }(\mathrm{OR}=3.4(1.3 \text { to } 8.9))\end{array}$ \\
\hline Kusel et al ${ }^{129}$ & $\begin{array}{l}\text { Atopy } \\
\text { Virus positive wheezing illness }\end{array}$ & $\begin{array}{l}\text { OR } 3.1 \text { ( } 1.5 \text { to } 6.4 \text { ) if atopic for wheeze at } 5 \text { years. OR } 3.9 \text { (1.4 to } \\
10.5) \text { if also wheezy illness }\end{array}$ \\
\hline
\end{tabular}

SHS and dampness and observed reduced asthma risk at 2 years for the intervention group (OR 0.7). ${ }^{48}$ The fifth study modified antenatal and postnatal exposures to HDM, pets, SHS, promoted breast feeding and delayed weaning, and asthma risk at 7 years was reduced in the intervention group (OR 0.4). ${ }^{49}$ Five observational studies related early life HDM exposure plus other 'dust' exposures to asthma: increased HDM and lipopolysaccharide (LPS) exposures were independently associated with increased symptoms by 7 years; $\mathrm{HDM} \geq 10 \mu \mathrm{g} / \mathrm{g}$ was associated with increased risk for asthma (OR 3.0) and each quartile increase in LPS was associated with increased risk for lifetime wheeze (OR 1.2).$^{50}$ Exposure to higher concentrations of cat allergen (but not HDM) was associated with increased asthma risk by 6 years of age OR for third versus lowest exposure quartile 2.6 (1.3 to 5.4$) ;^{51}$ other studies found no association between (1) infantile exposure to HDM and cat and cockroach allergen and wheeze at 2 years, ${ }^{52}$ (2) HDM, cat and dog allergen exposure and wheeze at 4 years, ${ }^{53}$ and (3) HDM and cat exposure and asthma at 7 years. ${ }^{54}$ One study reported increasing cockroach allergen exposure in infancy was positively associated with wheeze by age 5 years (OR 1.8) and, independently, the presence of a dog and higher concentrations of cat allergen exposure were associated with reduced wheeze risk (OR 0.3 and 0.6). ${ }^{55}$ Dog allergen exposure in infancy was not associated with asthma at 7 years per se but was associated with asthma in combination with exposure to SHS (OR 2.7) or elevated $\mathrm{NO}_{2}$ (OR 4.8). ${ }^{56}$ A final study observed interactions between exposures to SHS, breast feeding and recurrent respiratory infections and asthma. ${ }^{57}$

Pet exposure: There were two systematic reviews, one meta-analysis and six cohort studies identified and the results were highly inconsistent. One systematic review of nine studies concluded that exposure to pets around the 
time of birth may reduce risk for allergic disease (including asthma) where there is no family history of asthma, but no effect size was given. ${ }^{58}$ The second systematic review concluded that exposure to cats reduced the risk for asthma (OR 0.7) and to dogs increased asthma risk (OR 1.1) ${ }^{59}$ The meta-analysis found no evidence for cat exposure in early life being linked to asthma risk at age 6-10 years; there was a non-significant trend for dog ownership to be associated with reduced asthma risk (OR 0.8 (0.6 to 1.0$)){ }^{60}$ The cohort studies found early cat exposure to be associated with increased severe asthma at 4 years (OR 4.7), ${ }^{61}$ and reduced wheeze by age 5 years (OR $0.6^{62}$ and $0.3^{63}$ ), increased wheeze at 7 years (OR 1.2) ${ }^{64}$ and no association with asthma risk at $4^{65}$ or 8 years; ${ }^{66}$ in a post hoc analysis, early exposure to dog was linked to reduced late onset wheeze at 4 (OR $0.4(0.2$ to 1.0$)) .^{65}$ There was apparent synergy between exposure to high concentrations of cat allergen, SHS exposure and window pane condensation and increased risk for severe asthma at 4 years (OR 10.8 (2.0 to 59.6)). ${ }^{61}$

Other exposures: There was one systematic review identified relating exposure to farm living to asthma risk; data from 39 studies were identified, and despite differences in definitions for asthma and associations with exposure to living on a farm, there was a $25 \%$ reduction in risk of asthma for children living on a farm compared with controls (no CIs presented). ${ }^{67}$ A cohort study found an association between LPS concentration in mother's mattress when the infant was 3 months old and repeated wheeze by 2 years of age (OR 1.5 comparing highest with lowest quartile for exposure) ${ }^{68}$ A second cohort study reported an association between increased current exposure to mouse allergen and wheeze at 7 years of age (OR 1.4 $)^{69}$; there was no association between mouse allergen exposure in infancy and later wheeze. A third small cohort reported no association between exposure to cockroach allergen in infancy and wheeze in the first 2 years of life. ${ }^{52}$ Observational studies report associations between exposure to feather quilt in infancy and reduced asthma at 4 years compared with non-feather quilt $(\mathrm{OR} 0.4)^{70}$ and that a greater number of synthetic items of bedding (known to be HDM rich) during infancy was associated with increased risk for a history of asthma by 7 years (OR $1.8)^{71}$

HDM exposure: There were two intervention studies ${ }^{72} 73$ and one observational study, ${ }^{74}$ and none found an association between exposure in infancy ${ }^{72} 73$ or by 2 years of age ${ }^{74}$ and asthma at $3,{ }^{73} 6-7^{74}$ or 8 years of age. ${ }^{72}$

Outdoor allergens: Three cohort studies were identified and all found exposure was related to increased asthma risk. One study related fungal spores and pollen concentrations at the time of birth to wheeze at age 2 years and those born in autumn to winter (the fungal spore season) were at increased risk for wheezing (OR $3.1){ }^{75}$ A second study reported an association between increased grass pollen exposure between 4 and 6 months of age and increased asthma at 7 years of age (OR 1.4). ${ }^{76}$
The third study related tree canopy cover (a source of tree pollen and also of altered airflow and air quality) in infancy to asthma at 7 years and found a positive association (RR 1.2). ${ }^{77}$

\section{Air pollution}

One meta-analysis and eight additional cohort studies were identified, and while pollutants associated with combustion were associated with increased asthma risk, no single pollutant was consistently identified. The meta-analysis found that exposure to Nitrogen Dioxide $\left(\mathrm{NO}_{2}, \mathrm{OR}\right.$ 1.05), Nitric Oxide (OR 1.02) and Carbon Monoxide (CO, OR 1.06) were associated with higher prevalence of diagnosis of childhood asthma. Exposures to $\mathrm{SO}_{2}$ (OR 1.04) and particulates (OR 1.05) were associated with a higher prevalence of wheeze in children. ${ }^{78}$ Ambient lifetime $\mathrm{CO}$ exposure, but not $\mathrm{NO}_{2}$, ozone or particulates with mass less than 2.5 microns $\left(\mathrm{PM}_{2.5}\right)$, was associated with increased risk for wheeze at 5 years $(\mathrm{OR}$ 1.04 per ppm increased CO). ${ }^{79}$ A second cohort study found that ambient exposure to $\mathrm{NO}_{2}$, but not ozone, $\mathrm{SO}_{2}, \mathrm{PM}_{2.5}$ and $\mathrm{PM}_{10}$, was associated with increased asthma risk at 3 years (OR 1.2 per $5 \mathrm{ppb}$ increase) ${ }^{80} \mathrm{~A}$ third study related averaged lifetime exposure to ozone, $\mathrm{CO}, \mathrm{NO}_{2}, \mathrm{SO}_{2}$ and $\mathrm{PM}_{10}$, and found no association with asthma in 7-year-olds for the whole population, but among the $10 \%$ with previous bronchiolitis, asthma risk was increased (OR approximately 7) in association with higher exposures to ozone, $\mathrm{CO}$ and $\mathrm{NO}_{2}$ (table 2). ${ }^{81}$ Exposure to traffic-related particles (elemental carbon attributable to traffic) during infancy was associated with increased risk for asthma in 3-year -olds (OR 2.0) and co-exposure to high concentrations of domestic endotoxin increased the risk (OR 3.4).$^{82}$ One study found increased wheeze prevalence in 4-year-olds among those exposed to stop/go traffic compared with unexposed children $(23 \% \text { vs } 11 \%)^{83}$ and the second found that children with a lifetime exposure to higher traffic density were more likely to be diagnosed with asthma (OR 1.3) ${ }^{84}$ Exposure to high $\left(>4.1 \mu \mathrm{g} / \mathrm{m}^{3}\right)$ levels of $\mathrm{PM}_{2.5}$ during infancy were associated with increased risk for asthma in a small cohort (OR 3.1) ${ }^{85}$

\section{Dietary exposures \\ Maternal diet-food items}

There was one systematic review, one intervention study and five cohort studies identified, and some food items were linked to childhood asthma risk. The systematic review of 62 studies concluded that there was more convincing evidence for maternal fruit (compared with vegetable) intake during pregnancy to be associated with reduced risk for childhood asthma; ${ }^{86}$ there was only one study that identified maternal Mediterranean diet to outcome (persistent wheeze (OR 0.2) at age 6.5 years) and maternal exposure to fish was not included. A small intervention study where pregnant mothers took placebo or fish oil supplement found no difference in respiratory symptoms between treatment groups at 1 year. ${ }^{87}$ A study from 
Japan found reduced risk for wheeze at 16-24 months for children whose mother's diet had been least 'Westernised' (OR 0.6 for comparison with most 'Westernised'). ${ }^{88} \mathrm{~A}$ Mexican study found a protective effect of fish consumption during pregnancy on atopic wheeze (OR 0.6).$^{89}$ In Denmark, maternal intake of peanuts (OR 0.8) and tree nuts (OR 0.8) was inversely associated with asthma in children at 18 months of age. ${ }^{90}$ In Finland, low maternal consumption of leafy vegetables (OR 1.6), malaceous fruits (eg, apple, pear, OR 1.5) and chocolate (OR 1.4) were positively associated with the risk of wheeze in 5-year-old children. ${ }^{91}$ A final study found no association between maternal butter and margarine intake and asthma outcomes in children aged $5-6{ }^{92}$

\section{Maternal diet-specific nutrients}

There was one systematic review and eight cohort studies identified, and reduced exposure to some nutrients was associated with increased asthma risk. Meta-analysis within the systematic review found that (1) increasing maternal vitamin $D$ intake was associated with reduced risk for wheeze in the last year (OR 0.6, 4 studies) but not asthma at 5 years; (2) increasing maternal vitamin $\mathrm{E}$ intake was associated with reduced wheeze at 2 years (OR 0.7, 3 studies); (3) increased maternal plasma vitamin A was associated with reduced asthma risk (OR 0.3, 2 studies); and (4) there was no evidence for associations between maternal plasma zinc or selenium and asthma outcomes. ${ }^{86}$ Of five cohort studies published after the systematic review, four found no evidence linking maternal plasma vitamin $\mathrm{D}^{93-95}$ or vitamin $\mathrm{D}$ intake ${ }^{96}$ and asthma; one study found an inverse association between cord plasma vitamin $\mathrm{D}$ and risk for wheeze, but not asthma, by age 5 years (OR 0.95 per $10 \mathrm{nmol} / \mathrm{L}$ increase). ${ }^{97}$ One study found maternal fatty acid intake during the third trimester was associated with asthma outcome at 5 years (eg, higher $\alpha$-linoleic acid and palmitic acid intake associated with $\sim 40 \%$ reduced risk). ${ }^{98}$ Other studies found no association between maternal dietary antioxidants ${ }^{99}$ or folate $\mathrm{e}^{100}$ and vitamin $\mathrm{A}^{101}$ supplementation and childhood asthma outcomes.

\section{Exposure to milk during infancy}

In addition to the previously described complex interventions where milk exposure was modified, a number of studies were identified where only milk was the exposure of interest and there was evidence that early milk exposure was related to altered asthma risk.

Breast milk: One systematic review with meta-analysis, two cohort studies and one intervention study were identified. Meta-analysis of 31 studies found any breast feeding reduced risk for wheeze (OR 0.92) but increased risk for asthma (OR 1.10). ${ }^{102}$ Never breast feeding was associated with increased wheeze by 4 years (OR 1.4) ${ }^{103}$ and exclusive breast feeding was associated with reduced asthma risk at 5 (OR 0.9) ${ }^{104}$ but not at 6 years of age. The intervention study found that prolonged breast feeding (up to the age of 12 months) was associated with reduced asthma at 4 but not at 6 years of age. ${ }^{105}$ Maternal margarine intake (but not fatty acid or fish intake) while breast feeding was associated with increased risk for asthma at 5 years (HR 2.0).$^{98}$

Cow's milk formula: One systematic review, two intervention studies and one observational study were identified. A systematic review of 10 trials concluded that hydrolysed cow's milk formula, but not soya-based milk, reduced risk of wheezing in infancy (RR 0.4) compared with standard cow's milk formula. ${ }^{106}$ Modification of cow's milk formula either by a non-hydrolysing fermentation process or supplementation with fatty acids (arachidonic acid or docosahexaenoic acid) was associated with reduced risk for wheeze by $2(13 \% \text { vs } 35 \%)^{107}$ and 3 years of age (OR 0.3) ${ }^{108}$ compared with standard cow's milk formula. An observational study found no evidence for hydrolysed feed for the first 6 months reducing asthma risk at 3 years. ${ }^{109}$

\section{Dietary exposures during infancy}

There were two systematic reviews, two clinical trials and five observational studies identified; there were some associations between exposure to some dietary components and altered risk reported. Four observational studies related first dietary exposures to asthma outcomes, and one found evidence for early introduction of cereals by 6 months, and egg by 11 months was associated with $30-40 \%$ reduced risk for asthma at 5 years, ${ }^{110}$ and a second study found a direct relationship between age at introduction of oats and risk for asthma at 5 years (OR 0.4 for earliest vs latest age at introduction). ${ }^{111}$ Two other studies found no association between early or delayed introduction of any solids and asthma risk at $5^{112}$ and 6 years. ${ }^{113}$ A systematic review of 14 studies relating fish oil exposure during infancy and asthma (and other allergic outcomes) concluded that exposure was linked to a reduced risk of between $5 \%$ and $75 \% .{ }^{114}$ One cohort study found an association between the introduction of fish between 6 and 12 months and decreased risk for wheezing at 48 months (OR 0.6$) ;{ }^{115}$ however, the two previously discussed studies found no association between fish exposure and asthma ${ }^{112} 113$ and an intervention study of fish oil supplements in the first 6 months of life did not change risk for asthma symptoms at 12 months. ${ }^{116}$ A systematic review of two trials found no link between infant diet supplementation prebiotics and asthma risk, ${ }^{117}$ and a trial where infants were randomised to supplement with probiotic ( \pm prebiotic) or placebo also found no difference in asthma risk. ${ }^{118}$ One cohort study found no evidence for association between infant vitamin supplements and asthma risk, although among African-Americans, supplementation was associated with increased risk (OR 1.3). ${ }^{119}$

\section{Dietary exposure in childhood}

One RCT and six cohort studies were identified, and there was limited evidence linking early exposure to later increased asthma risk. Supplementation of milk with 
fermented milk containing lactobacillus during the first 2 years did not alter risk for asthma compared with placebo. ${ }^{120}$ One observational study found daily exposure to full cream milk at 2 years reduced risk for asthma 1 year later (OR 0.6 (0.4 to 0.9$)$ ). ${ }^{121}$ Exposure to organic food during the first 2 years ${ }^{122}$ and dietary oxidant at $5^{123}$ were not associated with altered risk for wheeze at 2 years or asthma at 8 years, respectively. Studies from the Netherlands found exposure to a 'western' diet at 14 months was associated with an increased risk for frequent wheeze at 3 years (RR 1.5), ${ }^{124}$ exposure to fruit in early childhood reduced risk for asthma at 8 years (OR 0.93 per item consumed day per week) ${ }^{125}$ and that increased plasma vitamin $\mathrm{D}$ at 4 years was associated with reduced asthma risk at 8 years (OR for highest vs lowest tertile 30.5$)^{126}$ but serum vitamin $D$ levels at 8 years were not associated with current asthma risk. ${ }^{126}$

\section{Respiratory virus infection}

There were six cohort studies identified and there was consistent evidence for infection associated with wheeze or that hospitalisation increased asthma risk. Parent reported lower respiratory tract infections during infancy were negatively associated with the risk of asthma at 7 years of age in one cohort (OR 0.5). ${ }^{127} \mathrm{~A}$ cohort study demonstrated that wheeze before 4 years of age was associated with increased risk for asthma at 6 years if rhinovirus (OR 9.8) was present; ${ }^{128}$ there was a borderline increase in risk if respiratory syncytial virus (RSV) was present (OR 2.6). A second cohort selected for familial risk for atopy also found rhinovirus positive (but not RSV positive) wheezing lower respiratory tract infection during infancy was associated with increased risk for asthma at age 5 years (OR 2.9). ${ }^{129}$ A third study observed an increased risk of asthma following infection with RSV, and this risk was higher in the months following the hospitalisation and lower with longer duration since hospitalisation (eg, RR 6.2 within 2 months of hospitalisation and RR 2.2 6-11 months after hospitalisation). ${ }^{130}$ Early daycare, a proxy for respiratory infections, was not associated with altered risk for asthma at age 8 years ${ }^{131}$ in one cohort but was associated with reduced asthma risk at 8 years in a second study (HR 0.9). ${ }^{132}$

\section{Other infections}

One small cohort study observed reduced risk for wheeze at 18 months for children whose parents cleaned their dummy/pacifier by sucking it (OR $0.1(0.01$ to 1.0$)$ ) compared with other cleaning practices. ${ }^{133}$ A second cohort study found no evidence for infection in preschool children (either serologically proven or isolated from stool samples) and wheeze by 11 years. ${ }^{134}$

\section{Medications}

\section{Antibiotics}

Three systematic reviews were identified that related antenatal $^{135}$ and postnatal ${ }^{135-137}$ exposure to antibiotics and asthma outcomes. There was evidence that antenatal and postnatal exposures were associated with increased risk for early asthma symptoms (eg, OR 1.2 for antenatal exposure and 1.5 for postnatal exposure) ${ }^{135}$ but all three systematic reviews concluded that this association was explained by reverse causation. One systematic review demonstrated that the OR fell from 1.3 to 1.1 when reverse causation was considered. ${ }^{136}$

\section{Paracetamol}

Three systematic reviews were identified and these linked antenatal $^{138}$ and postnatal ${ }^{137-139}$ exposure to paracetamol to the risk of asthma symptoms. There were associations between paracetamol exposure and the development of asthma OR $1.3^{139}$ and wheeze OR 1.2. ${ }^{138}$ The third systematic review did not present an effect size and suggested that any association was by reverse causation. $^{137}$

\section{Other maternal exposures during pregnancy}

A whole-population study found treatment during the second and third trimester with the following were associated with increased risk for asthma: antibiotics (OR 1.1); drugs for gastro-oesophageal reflux (OR 1.3); opiates (OR 1.6); and thyroid drugs (OR 1.3). There was no association with paracetamol prescribing. ${ }^{140}$ Five cohort studies related various maternal exposures during pregnancy to early childhood wheeze and reported the following associations: exposure to dietary dioxins and polychlorinated biphenyls was associated with increased wheeze by 3 years (OR 2.7) $;^{141}$ exposure to BPA was positively associated with a transient increase in wheeze in one study (OR for wheeze at 6 months 2.3, highest vs lowest exposure $)^{142}$ and inversely associated with transient wheeze in a second study (OR for wheeze at 5 years 0.7 per increase in $\log$ transformed $\mathrm{BPA})^{36}$; each $10 \%$ increase in exposure to dichlorodiphenyldichloroethylene (a product of the pesticide dichlorodiphenyltrichloroethane (DDT)) was associated with increased wheeze at 12-14 months of age (RR 1.11); ${ }^{143}$ each unit increase in in utero electromagnetic exposure was linked with increased risk for asthma at 13 years (HR 1.15). ${ }^{144}$

\section{DISCUSSION}

The aim of this systematic review was to provide an overview of the literature describing associations between environmental exposures in early life and asthma outcomes by 9 years of age. This review is mostly based on observational studies and is likely to be influenced by submission bias (where investigators do not submit papers that find no associations which challenge current paradigms) and/or publication bias. In addition, reverse causation or confounding may explain some associations reported, for example, postnatal exposures to antibiotics, paracetamol and perhaps pets. Moreover, observational studies cannot prove causation and most intervention studies found no effect on outcome even where studies indicated a potentially important mechanism, for 
example, HDM interventions. Given these caveats, we believe that three major conclusions can be drawn. First, there was a moderately strong level of evidence (ie, RCT, systematic review or meta-analysis) for the presence of associations between most exposures and asthma risk but the literature remains relatively deficient for exposures to infection and domestic combustion (both of which are likely to be important on a global basis). Second, where associations were present, these were of small-moderate effect size by our predefined standard. Third, we identified interactions between exposures (most commonly SHS) and/or atopy which increased the risk of that exposure being associated with asthma. Given that there is no prospect of a cure for asthma, modification of the environment in early life currently offers the best hope of reducing the burden of asthma in the population and an overview of all exposures such as we present here may be of use to policymakers, healthcare workers and lobbying groups.

There is no single exposure which seems likely to cause asthma and even 'single' exposures are invariably contaminated by other exposures. There was consistent evidence in the literature for associations between exposures to SHS, inhaled chemicals, mould, respiratory viruses, ambient air pollutants and maternal dietary components, and increased asthma risk. However, each of these is a complex exposure and there was evidence of interaction between all these exposures. There is evidence that asthma risk may be related to diversity of exposure to fungus and not exposure per $\mathrm{se}^{145}$ and our findings are consistent with this idea. There were inconsistent associations between asthma and exposures to pets, breast feeding and infant diet when considered separately but those intervention studies where asthma risk was successfully reduced often included modifications to some or all of these exposures. There is further evidence that asthma risk can be reduced by early exposure to an environment that is diverse in many inhaled and ingested factors common to the human environment for millennia, such as animal dander, LPS, fungi and breast milk (but not including man-made chemicals).

There are a number of limitations to this systematic review in addition to those already described. First, in the absence of a gold standard definition of asthma, different outcomes have been used, for example, asthma or wheeze; these may not be interchangeable and have different associations with a given exposure. Second, associations reported may not be persistent: exposure to breast feeding is an example of a waning effect of a given exposure over time, presumably as current exposures modify the effect of past exposures. Third, the upper age of study participants was 9 years and this meant that many highly cited studies describing associations between exposure and asthma risk in older children were not included. ${ }^{146}$ Fourth, in our methodology we included only the latest paper from cohorts where associations may have been reported at several different ages and this will mean that transient associations are not captured; for example, we have interpreted an intervention study where breast feeding was successfully prolonged as having no effect on asthma at 6 years ${ }^{105}$ but the exposure was associated with reduced asthma symptoms in this cohort at ages $2^{147}$ and $4^{148}$ years. Finally, it is possible that a given exposure may have a different effect on asthma risk between populations where different genetic and/or epigenetic factors may be acting.

In summary, we have reviewed the literature for associations between all environmental exposures and the development of asthma in children aged under 9 years. Early life exposures to exhaled tobacco smoke, VOCs, mould, breast feeding, pets and many dietary factors appear to be important to the development of asthma and interactions between these exposures further increase this risk, particularly in individuals with allergic parents. Complex interventions in early life are challenging ${ }^{149}$ but the evidence in the observational literature and from small intervention studies demonstrates that approaches using this study design may lead to stronger public health advice stating that interventions which alter multiple early life environmental encounters are able to modify asthma risk in this age group.

\section{Author affiliations}

${ }^{1}$ Occupational and Environmental Medicine, University of Aberdeen, Aberdeen, UK

${ }^{2}$ Department of Child Health, University of Aberdeen, Aberdeen, UK

${ }^{3}$ Institute of Occupational Medicine, Edinburgh, UK

${ }^{4}$ Environmental and Respiratory Medicine, University of Birmingham, Birmingham, UK

Contributors JGA, HC and SWT were involved in conception and design. SD, $\mathrm{ED}, \mathrm{AF}, \mathrm{KD}$ and $\mathrm{FA}$ undertook the analysis. SD drafted the initial version of the manuscript and all authors contributed to revisions. SWT is the guarantor of this work.

Funding This study was funded by Good Places better Health Initiative of the Scottish Government, grant number EV028 RGC 1880.

Competing interests None.

Provenance and peer review Not commissioned; externally peer reviewed.

Data sharing statement No additional data are available.

Open Access This is an Open Access article distributed in accordance with the Creative Commons Attribution Non Commercial (CC BY-NC 4.0) license, which permits others to distribute, remix, adapt, build upon this work noncommercially, and license their derivative works on different terms, provided the original work is properly cited and the use is non-commercial. See: http:// creativecommons.org/licenses/by-nc/4.0/

\section{REFERENCES}

1. Eder W, Ege MJ, von Mutius E. The asthma epidemic. N Engl J Med 2006;355:2226-35.

2. Kozyrskyj AL, Bahreinian S, Azad MB. Early life exposures: impact on asthma and allergic disease. Curr Opin Allergy Clin Immunol 2011;11:400-6.

3. Kabesch M, Michel S, Tost J. Epigenetic mechanisms and the relationship to childhood asthma. Eur Respir J 2010;36:950-61.

4. Ahluwalia SK, Matsui EC. The indoor environment and its effects on childhood asthma. Curr Opin Allergy Clin Immunol 2011;11:137-43.

5. Vork KL, Broadwin RL, Blaisdell RJ. Developing asthma in childhood from exposure to secondhand tobacco smoke: insights from a meta-regression. Environ Health Perspect 2007;115:1394-400. 
6. Bloomberg GR. The influence of environment, as represented by diet and air pollution, upon incidence and prevalence of wheezing illnesses in young children. Curr Opin Allergy Clin Immunol 2011;11:144-9.

7. Jackson DJ, Lemanske RF Jr. The role of respiratory virus infections in childhood asthma inception. Immunol Allergy Clin North Am 2010;30:513-22.

8. Le Cann P, Bonvallot N, Glorennec P, et al. Indoor environment and children's health: recent developments in chemical, biological, physical and social aspects. Int J Hyg Environ Health 2011;215:1-18

9. Rabinovitch N, Silveira L, Gelfand EW, et al. The response of children with asthma to ambient particulate is modified by tobacco smoke exposure. Am J Respir Crit Care Med 2011;184:1350-7.

10. Herr M, Just J, Nikasinovic L, et al. Influence of host and environmental factors on wheezing severity in infants: findings from the PARIS birth cohort. Clin Exp Allergy 2012;42:275-83.

11. Dick S, Doust E, Cowie $\mathrm{H}$, et al. Associations between environmental exposures and asthma control and exacerbations in young children-a systematic review. BMJ Open 2014;4:e003827.

12. Neuman A, Hohmann $\mathrm{C}$, Orsini $\mathrm{N}$, et al. Maternal smoking in pregnancy and asthma in preschool children: a pooled analysis of eight birth cohorts. Am J Respir Crit Care Med 2012;186:1037-43.

13. Jedrychowski W, Perera FP, Maugeri U, et al. Early wheezing phenotypes and severity of respiratory illness in very early childhood: study on intrauterine exposure to fine particle matter. Environ Int 2009;35:877-84.

14. Lannero E, Wickman M, Pershagen G, et al. Maternal smoking during pregnancy increases the risk of recurrent wheezing during the first years of life (BAMSE). Respir Res 2006;7:3.

15. Jaakkola JJ, Gissler M. Maternal smoking in pregnancy, fetal development, and childhood asthma. Am J Public Health 2004;94:136-40.

16. Robison RG, Kumar R, Arguelles LM, et al. Maternal smoking during pregnancy, prematurity and recurrent wheezing in early childhood. Pediatr Pulmonol 2011;47:666-73.

17. Tanaka K, Miyake Y, Sasaki S, et al. Maternal smoking and environmental tobacco smoke exposure and the risk of allergic diseases in Japanese infants: the Osaka Maternal and Child Health Study. J Asthma 2008;45:833-8.

18. Haberg SE, Stigum H, Nystad W, et al. Effects of pre- and postnatal exposure to parental smoking on early childhood respiratory health. Am J Epidemiol 2007;166:679-86.

19. Martinez FD, Cline M, Burrows B. Increased incidence of asthma in children of smoking mothers. Pediatrics 1992;89:21-6.

20. Hunt A, Crawford JA, Rosenbaum PF, et al. Levels of household particulate matter and environmental tobacco smoke exposure in the first year of life for a cohort at risk for asthma in urban Syracuse, NY. Environ Int 2011;37:1196-205.

21. Willers SM, Brunekreef $B$, Oldenwening $M$, et al. Gas cooking, kitchen ventilation, and asthma, allergic symptoms and sensitization in young children-the PIAMA study. Allergy 2006;61:563-8.

22. Jung $\mathrm{KH}$, Hsu SI, Yan B, et al. Childhood exposure to fine particulate matter and black carbon and the development of new wheeze between ages 5 and 7 in an urban prospective cohort. Environ Int 2012;45:44-50.

23. Yeatts KB, El-Sadig M, Leith D, et al. Indoor air pollutants and health in the United Arab Emirates. Environ Health Perspect 2012;120:687-94.

24. Abdul Wahab A, Mostafa OA. Arabian incense exposure among Qatari asthmatic children. A possible risk factor. Saudi Med J 2007;28:476-8.

25. Padhi BK, Padhy PK. Domestic fuels, indoor air pollution, and children's health. Ann N Y Acad Sci 2008;1140:209-17.

26. McGwin G Jr, Lienert J, Kennedy JI Jr. Formaldehyde exposure and asthma in children: a systematic review. Ciencia Saude Coletiva 2011;16:3845-52.

27. Diez U, Rehwagen M, Rolle-Kampczyk U, et al. Redecoration of apartments promotes obstructive bronchitis in atopy risk infantsresults of the LARS Study. Int J Hyg Environ Health 2003;206:173-9.

28. Kim JL, Elfman L, Mi Y, et al. Indoor molds, bacteria, microbial volatile organic compounds and plasticizers in schoolsassociations with asthma and respiratory symptoms in pupils. Indoor Air 2007;17:153-63.

29. Rumchev KB, Spickett JT, Bulsara MK, et al. Domestic exposure to formaldehyde significantly increases the risk of asthma in young children. Eur Respir J 2002;20:403-8.

30. Rumchev K, Spickett J, Bulsara M, et al. Association of domestic exposure to volatile organic compounds with asthma in young children. Thorax 2004;59:746-51.
31. Font-Ribera L, Villanueva CM, Nieuwenhuijsen MJ, et al. Swimming pool attendance, asthma, allergies, and lung function in the Avon Longitudinal Study of Parents and Children cohort. Am J Respir Crit Care Med 2011;183:582-8.

32. Schoefer Y, Zutavern A, Brockow I, et al. Health risks of early swimming pool attendance. Int J Hyg Environ Health 2008;211:367-3.

33. Jaakkola JJ, Knight TL. The role of exposure to phthalates from polyvinyl chloride products in the development of asthma and allergies: a systematic review and meta-analysis. Environ Health Perspect 2008;116:845-3.

34. Henderson J, Sherriff A, Farrow A, et al. Household chemicals, persistent wheezing and lung function: effect modification by atopy? Eur Respir J 2008;31:547-54.

35. Jung $\mathrm{KH}$, Yan $\mathrm{B}$, Moors $\mathrm{K}$, et al. Repeated exposure to polycyclic aromatic hydrocarbons and asthma: effect of seroatopy. Ann Allergy Asthma Immunol 2012;109:249-54.

36. Donohue KM, Miller RL, Perzanowski MS, et al. Prenatal and postnatal bisphenol A exposure and asthma development among inner-city children. J Allergy Clin Immunol 2013;131:736-42.

37. Wichmann FA, Muller A, Busi LE, et al. Increased asthma and respiratory symptoms in children exposed to petrochemical pollution. J Allergy Clin Immunol 2009;123:632-8.

38. Rusconi F, Catelan D, Accetta G, et al. Asthma symptoms, lung function, and markers of oxidative stress and inflammation in children exposed to oil refinery pollution. J Asthma 2011;48:84-90.

39. Tischer C, Chen CM, Heinrich J. Association between domestic mould and mould components, and asthma and allergy in children: a systematic review. Eur Respir J 2011;38:812-14.

40. Tischer CG, Hohmann C, Thiering E, et al. Meta-analysis of mould and dampness exposure on asthma and allergy in eight European birth cohorts: an ENRIECO initiative. Allergy 2011;66:1570-9.

41. Iossifova $\mathrm{YY}$, Reponen $\mathrm{T}$, Ryan $\mathrm{PH}$, et al. Mold exposure during infancy as a predictor of potential asthma development. Ann Allergy Asthma Immunol 2009;102:131-7.

42. Jaakkola JJ, Hwang BF, Jaakkola N. Home dampness and molds, parental atopy, and asthma in childhood: a six-year population-based cohort study. Environ Health Perspect 2005;113:357-61.

43. Reponen T, Vesper S, Levin L, et al. High environmental relative moldiness index during infancy as a predictor of asthma at 7 years of age. Ann Allergy Asthma Immunol 2011;107:120-6.

44. Reponen T, Lockey J, Bernstein DI, et al. Infant origins of childhood asthma associated with specific molds. J Allergy Clin Immunol 2012;130:639-44.

45. Marks GB, Mihrshahi S, Kemp AS, et al. Prevention of asthma during the first 5 years of life: a randomized controlled trial. J Allergy Clin Immunol 2006;118:53-61.

46. Arshad SH, Bateman B, Sadeghnejad A, et al. Prevention of allergic disease during childhood by allergen avoidance: the Isle of Wight prevention study. J Allergy Clin Immunol 2007;119:307-13.

47. Maas T, Dompeling E, Muris JW, et al. Prevention of asthma in genetically susceptible children: a multifaceted intervention trial focussed on feasibility in general practice. Pediatr Allergy Immunol 2011;22:794-802.

48. Dotterud CK, Storro O, Simpson MR, et al. The impact of pre- and postnatal exposures on allergy related diseases in childhood: a controlled multicentre intervention study in primary health care. BMC Public Health 2013;13:123.

49. Chan-Yeung M, Ferguson A, Watson W, et al. The Canadian Childhood Asthma Primary Prevention Study: outcomes at 7 years of age. J Allergy Clin Immunol 2005;116:49-55.

50. Celedon JC, Milton DK, Ramsey CD, et al. Exposure to dust mite allergen and endotoxin in early life and asthma and atopy in childhood. J Allergy Clin Immunol 2007;120:144-9.

51. Torrent M, Sunyer J, Garcia R, et al. Early-life allergen exposure and atopy, asthma, and wheeze up to 6 years of age. Am J Respir Crit Care Med 2007;176:446-53.

52. Finn PW, Boudreau JO, $\mathrm{He} \mathrm{H}$, et al. Children at risk for asthma: home allergen levels, lymphocyte proliferation, and wheeze. J Allergy Clin Immunol 2000;105:933-42.

53. Brussee JE, Smit HA, van Strien RT, et al. Allergen exposure in infancy and the development of sensitization, wheeze, and asthma at 4 years. J Allergy Clin Immunol 2005;115:946-52.

54. Lau S, Illi S, Sommerfeld C, et al. Early exposure to house-dust mite and cat allergens and development of childhood asthma: a cohort study. Multicentre Allergy Study Group. Lancet 2000;356:1392-7.

55. Litonjua AA, Milton DK, Celedon JC, et al. A longitudinal analysis of wheezing in young children: the independent effects of early life exposure to house dust endotoxin, allergens, and pets. J Allergy Clin Immunol 2002;110:736-42. 
56. Carlsten $\mathrm{C}$, Brauer M, Dimich-Ward $\mathrm{H}$, et al. Combined exposure to dog and indoor pollution: incident asthma in a high-risk birth cohort. Eur Respir J 2011;37:324-30.

57. Karmaus W, Dobai AL, Ogbuanu I, et al. Long-term effects of breastfeeding, maternal smoking during pregnancy, and recurrent lower respiratory tract infections on asthma in children. $J$ Asthma 2008:45:688-95.

58. Lodge CJ, Allen KJ, Lowe AJ, et al. Perinatal cat and dog exposure and the risk of asthma and allergy in the urban environment: a systematic review of longitudinal studies. Clin Dev Immunol 2012;2012:176484.

59. Takkouche B, Gonzalez-Barcala FJ, Etminan M, et al. Exposure to furry pets and the risk of asthma and allergic rhinitis: meta-analysis. Allergy 2008;63:857-64.

60. Lodrup Carlsen KC, Roll S, Carlsen KH, et al. Does pet ownership in infancy lead to asthma or allergy at school age? Pooled analysis of individual participant data from 11 European birth cohorts. PLoS ONE 2012;7:e43214.

61. Melen E, Wickman M, Nordvall SL, et al. Influence of early and current environmental exposure factors on sensitization and outcome of asthma in pre-school children. Allergy 2001;56:646-52.

62. Celedon JC, Litonjua AA, Ryan L, et al. Exposure to cat allergen, maternal history of asthma, and wheezing in first 5 years of life. Lancet 2002;360:781-2.

63. Perzanowski MS, Chew GL, Divjan A, et al. Cat ownership is a risk factor for the development of anti-cat lgE but not current wheeze at age 5 years in an inner-city cohort. $J$ Allergy Clin Immunol 2008;121:1047-52.

64. Brunekreef B, Von Mutius E, Wong G, et al. Exposure to cats and dogs, and symptoms of asthma, rhinoconjunctivitis, and eczema. Epidemiology 2012;23:742-50.

65. Sandin A, Bjorksten B, Braback L. Development of atopy and wheezing symptoms in relation to heredity and early pet keeping in a Swedish birth cohort. Pediatr Allergy Immunol 2004;15:316-22.

66. Kerkhof $\mathrm{M}$, Wijga AH, Brunekreef $\mathrm{B}$, et al. Effects of pets on asthma development up to 8 years of age: the PIAMA study. Allergy 2009;64:1202-8.

67. Genuneit J. Exposure to farming environments in childhood and asthma and wheeze in rural populations: a systematic review with meta-analysis. Pediatr Allergy Immunol 2012;23:509-18.

68. Bolte G, Bischof W, Borte M, et al. Early endotoxin exposure and atopy development in infants: results of a birth cohort study. Clin Exp Allergy 2003;33:770-6.

69. Phipatanakul W, Celedon JC, Hoffman EB, et al. Mouse allergen exposure, wheeze and atopy in the first seven years of life. Allergy 2008:63:1512-18

70. Nafstad P, Nystad W, Jaakkola JJ. The use of a feather quilt, childhood asthma and allergic rhinitis: a prospective cohort study. Clin Exp Allergy 2002;32:1150-4.

71. Trevillian LF, Ponsonby AL, Dwyer T, et al. Infant sleeping environment and asthma at 7 years: a prospective cohort study. Am $J$ Public Health 2005;95:2238-45.

72. Gehring U, de Jongste JC, Kerkhof M, et al. The 8-year follow-up of the PIAMA intervention study assessing the effect of mite-impermeable mattress covers. Allergy 2012;67:248-56.

73. Woodcock A, Lowe LA, Murray CS, et al. Early life environmental control: effect on symptoms, sensitization, and lung function at age 3 years. Am J Respir Crit Care Med 2004;170:433-9.

74. Carter PM, Peterson EL, Ownby DR, et al. Relationship of house-dust mite allergen exposure in children's bedrooms in infancy to bronchial hyperresponsiveness and asthma diagnosis by age 6 to 7. Ann Allergy Asthma Immunol 2003;90:41-4.

75. Harley KG, Macher JM, Lipsett M, et al. Fungi and pollen exposure in the first months of life and risk of early childhood wheezing. Thorax 2009;64:353-8.

76. Erbas B, Lowe AJ, Lodge CJ, et al. Persistent pollen exposure during infancy is associated with increased risk of subsequent childhood asthma and hayfever. Clin Exp Allergy 2013;43:337-43.

77. Lovasi GS, O'Neil-Dunne JP, Lu JW, et al. Urban tree canopy and asthma, wheeze, rhinitis, and allergic sensitization to tree pollen in a New York City birth cohort. Environ Health Perspect 2013;121:494-500.

78. Gasana J, Dillikar D, Mendy A, et al. Motor vehicle air pollution and asthma in children: a meta-analysis. Environ Res 2012;117:36-45.

79. Rodriguez C, Tonkin R, Heyworth J, et al. The relationship between outdoor air quality and respiratory symptoms in young children. Int J Environ Health Res 2007:17:351-60.

80. Nishimura KK, Galanter JM, Roth LA, et al. Early-life air pollution and asthma risk in minority children. The GALA II and SAGE II studies. Am J Respir Crit Care Med 2013;188:309-18.
81. Kim BJ, Seo JH, Jung $\mathrm{YH}$, et al. Air pollution interacts with past episodes of bronchiolitis in the development of asthma. Allergy 2013;68:517-23.

82. Ryan $\mathrm{PH}$, Bernstein DI, Lockey J, et al. Exposure to traffic-related particles and endotoxin during infancy is associated with wheezing at age 3 years. Am J Respir Crit Care Med 2009;180:1068-75.

83. Bernstein DI. Traffic-related pollutants and wheezing in children. J Asthma 2012;49:5-7.

84. Patel MM, Quinn JW, Jung KH, et al. Traffic density and stationary sources of air pollution associated with wheeze, asthma, and immunoglobulin $\mathrm{E}$ from birth to age 5 years among New York City children. Environ Res 2011;111:1222-9.

85. Carlsten C, Dybuncio A, Becker A, et al. Traffic-related air pollution and incident asthma in a high-risk birth cohort. Occup Environ Med 2011;68:291-5.

86. Nurmatov U, Devereux G, Sheikh A. Nutrients and foods for the primary prevention of asthma and allergy: systematic review and meta-analysis. J Allergy Clin Immunol 2011;127:724-33.

87. Dunstan JA, Mori TA, Barden A, et al. Fish oil supplementation in pregnancy modifies neonatal allergen-specific immune responses and clinical outcomes in infants at high risk of atopy: a randomized, controlled trial. J Allergy Clin Immunol 2003;112:1178-84.

88. Miyake Y, Sasaki S, Tanaka K, et al. Consumption of vegetables, fruit, and antioxidants during pregnancy and wheeze and eczema in infants. Allergy 2010;65:758-65.

89. Romieu I, Torrent M, Garcia-Esteban R, et al. Maternal fish intake during pregnancy and atopy and asthma in infancy. Clin Exp Allergy 2007;37:518-25

90. Maslova E, Granstrom C, Hansen S, et al. Peanut and tree nut consumption during pregnancy and allergic disease in children-should mothers decrease their intake? Longitudinal evidence from the Danish National Birth Cohort. J Allergy Clin Immunol 2012;130:724-32.

91. Erkkola M, Nwaru BI, Kaila M, et al. Risk of asthma and allergic outcomes in the offspring in relation to maternal food consumption during pregnancy: a Finnish birth cohort study. Pediatr Allergy Immunol 2012;23:186-94.

92. Nwaru BI, Erkkola M, Lumia M, et al. Maternal intake of fatty acids during pregnancy and allergies in the offspring. $\mathrm{Br} J$ Nutr 2012;108:720-32.

93. Pike KC, Inskip HM, Robinson S, et al. Maternal late-pregnancy serum 25-hydroxyvitamin $D$ in relation to childhood wheeze and atopic outcomes. Thorax 2012;67:950-6.

94. Morales E, Romieu I, Guerra S, et al. Maternal vitamin D status in pregnancy and risk of lower respiratory tract infections, wheezing, and asthma in offspring. Epidemiology 2012;23:64-71.

95. Hollams EM, Hart PH, Holt BJ, et al. Vitamin D and atopy and asthma phenotypes in children: a longitudinal cohort study. Eur Respir J 2011;38:1320-7.

96. Miyake Y, Sasaki S, Tanaka K, et al. Maternal B vitamin intake during pregnancy and wheeze and eczema in Japanese infants aged 16-24 months: the Osaka Maternal and Child Health Study. Pediatr Allergy Immunol 2011;22:69-74.

97. Camargo CA Jr, Ingham T, Wickens $\mathrm{K}$, et al. Cord-blood 25-hydroxyvitamin $D$ levels and risk of respiratory infection, wheezing, and asthma. Pediatrics 2011:127:e180-7.

98. Lumia M, Luukkainen $\mathrm{P}$, Tapanainen $\mathrm{H}$, et al. Dietary fatty acid composition during pregnancy and the risk of asthma in the offspring. Pediatr Allergy Immunol 2011;22:827-35.

99. Nwaru BI, Erkkola M, Ahonen S, et al. Intake of antioxidants during pregnancy and the risk of allergies and asthma in the offspring. Eur $J$ Clin Nutr 2011;65:937-43.

100. Martinussen MP, Risnes KR, Jacobsen GW, et al. Folic acid supplementation in early pregnancy and asthma in children aged 6 years. Am J Obstet Gynaecol 2011;206:72.e1-7.

101. Checkley W, West KP Jr, Wise RA, et al. Supplementation with vitamin A early in life and subsequent risk of asthma. Eur Respir $J$ 2011;38:1310-19.

102. Brew BK, Allen CW, Toelle BG, et al. Systematic review and meta-analysis investigating breast feeding and childhood wheezing illness. Paediatr Perinat Epidemiol 2011;25:507-18.

103. Sonnenschein-van der Voort AM, Jaddoe VW, van der Valk RJ, et al. Duration and exclusiveness of breastfeeding and childhood asthma-related symptoms. Eur Respir J 2012;39:81-9.

104. Silvers KM, Frampton CM, Wickens $\mathrm{K}$, et al. Breastfeeding protects against current asthma up to 6 years of age. $J$ Pediatr 2012;160:991-6.

105. Kramer MS, Matush L, Vanilovich I, et al. Effect of prolonged and exclusive breast feeding on risk of allergy and asthma: cluster randomised trial. BMJ 2007;335:20. 
106. Ram F, Scarlett J. Development of childhood asthma and formula milk. Br J Midwifery 2004;12:221-30.

107. Morisset M, Aubert-Jacquin C, Soulaines $\mathrm{P}$, et al. A non-hydrolyzed, fermented milk formula reduces digestive and respiratory events in infants at high risk of allergy. Eur J Clin Nutr 2011;65:175-83.

108. Birch EE, Khoury JC, Berseth CL, et al. The impact of early nutrition on incidence of allergic manifestations and common respiratory illnesses in children. J Pediatr 2010;156:902-6.

109. Kuo HC, Liu CA, Ou CY, et al. Partial protein-hydrolyzed infant formula decreased food sensitization but not allergic diseases in a prospective birth cohort study. Int Arch Allergy Immunol 2011:154:310-17.

110. Nwaru BI, Takkinen HM, Niemela O, et al. Timing of infant feeding in relation to childhood asthma and allergic diseases. J Allergy Clin Immunol 2013;131:78-86.

111. Virtanen SM, Kaila M, Pekkanen J, et al. Early introduction of oats associated with decreased risk of persistent asthma and early introduction of fish with decreased risk of allergic rhinitis. Br J Nutr 2010;103:266-73.

112. Mihrshahi S, Ampon R, Webb K, et al. The association between infant feeding practices and subsequent atopy among children with a family history of asthma. Clin Exp Allergy 2007;37:671-9.

113. Zutavern A, Brockow I, Schaaf B, et al. Timing of solid food introduction in relation to eczema, asthma, allergic rhinitis, and food and inhalant sensitization at the age of 6 years: results from the prospective birth cohort study LISA. Pediatrics 2008;121:e44-52.

114. Kremmyda LS, Vlachava M, Noakes PS, et al. Atopy risk in infants and children in relation to early exposure to fish, oily fish, or long-chain omega-3 fatty acids: a systematic review. Clin Rev Allergy Immunol 2011:41:36-66.

115. Kiefte-de Jong JC, de Vries $\mathrm{JH}$, Franco $\mathrm{OH}$, et al. Fish consumption in infancy and asthma-like symptoms at preschool age. Pediatrics 2012:130:1060-8.

116. D'Vaz N, Meldrum SJ, Dunstan JA, et al. Postnatal fish oil supplementation in high-risk infants to prevent allergy: randomized controlled trial. Pediatrics 2012;130:674-82.

117. Osborn DA, Sinn JK. Prebiotics in infants for prevention of allergy. Cochrane Database Syst Rev 2007;3:CD006474.

118. Kukkonen AK, Kuitunen M, Savilahti E, et al. Airway inflammation in probiotic-treated children at 5 years. Pediatr Allergy Immunol 2011:22:249-51.

119. Milner JD, Stein DM, McCarter R, et al. Early infant multivitamin supplementation is associated with increased risk for food allergy and asthma. Pediatrics 2004:114:27-32.

120. Giovannini M, Agostoni C, Riva E, et al. A randomized prospective double blind controlled trial on effects of long-term consumption of fermented milk containing Lactobacillus casei in pre-school children with allergic asthma and/or rhinitis. Pediatr Res 2007;62:215-20.

121. Wijga AH, Smit HA, Kerkhof M, et al. Association of consumption of products containing milk fat with reduced asthma risk in pre-school children: the PIAMA birth cohort study. Thorax 2003;58:567-2.

122. Kummeling I, Thiis $\mathrm{C}$, Huber M, et al. Consumption of organic foods and risk of atopic disease during the first 2 years of life in the Netherlands. Br J Nutr 2008;99:598-605.

123. Patel S, Murray CS, Woodcock A, et al. Dietary antioxidant intake, allergic sensitization and allergic diseases in young children. Allergy 2009;64:1766-72.

124. Tromp II, Kiefte-de Jong JC, Lebon A, et al. The introduction of allergenic foods and the development of reported wheezing and eczema in childhood: the Generation R study. Arch Pediatr Adolesc Med 2011;165:933-8.

125. Willers SM, Wijga AH, Brunekreef $B$, et al. Childhood diet and asthma and atopy at 8 years of age: the PIAMA birth cohort study. Eur Respir J 2011;37:1060-7.

126. van Oeffelen AA, Bekkers MB, Smit HA, et al. Serum micronutrient concentrations and childhood asthma: the PIAMA birth cohort study. Pediatr Allergy Immunol 2011;22:784-93.

127. Illi S, von Mutius E, Lau S, et al. Early childhood infectious diseases and the development of asthma up to school age: a birth cohort study. BMJ 2001;322:390-5.
128. Jackson DJ, Gangnon RE, Evans MD, et al. Wheezing rhinovirus illnesses in early life predict asthma development in high-risk children. Am J Respir Crit Care Med 2008; 178:667-2.

129. Kusel MM, de Klerk NH, Kebadze T, et al. Early-life respiratory viral infections, atopic sensitization, and risk of subsequent development of persistent asthma. J Allergy Clin Immunol 2007; $119: 1105-10$.

130. Stensballe LG, Simonsen JB, Thomsen SF, et al. The causal direction in the association between respiratory syncytial virus hospitalization and asthma. J Allergy Clin Immunol 2009;123:131-7.

131. Caudri D, Wijga A, Scholtens $\mathrm{S}$, et al. Early daycare is associated with an increase in airway symptoms in early childhood but is no protection against asthma or atopy at 8 years. Am J Respir Crit Care Med 2009;180:491-8.

132. Midodzi WK, Rowe BH, Majaesic CM, et al. Early life factors associated with incidence of physician-diagnosed asthma in preschool children: results from the Canadian Early Childhood Development cohort study. J Asthma 2010;47:7-13.

133. Hesselmar B, Sjoberg F, Saalman R, et al. Pacifier cleaning practices and risk of allergy development. Pediatrics 2013;131:e1829-37.

134. Alcantara-Neves NM, Veiga RV, Dattoli VC, et al. The effect of single and multiple infections on atopy and wheezing in children. J Allergy Clin Immunol 2012;129:359-67.

135. Murk W, Risnes KR, Bracken MB. Prenatal or early-life exposure to antibiotics and risk of childhood asthma: a systematic review. Pediatrics 2010;127:1125-38.

136. Penders J, Kummeling I, Thijs C. Infant antibiotic use and wheeze and asthma risk: a systematic review and meta-analysis. Eur Respir J 2011;38:295-302.

137. Heintze K, Petersen KU. The case of drug causation of childhood asthma: antibiotics and paracetamol. Eur J Clin Pharmacol 2013;69:1197-209.

138. Eyers $\mathrm{S}$, Weatherall $\mathrm{M}$, Jefferies $\mathrm{S}$, et al. Paracetamol in pregnancy and the risk of wheezing in offspring: a systematic review and meta-analysis. Clin Exp Allergy 2011;41:482-9.

139. Etminan M, Sadatsafavi M, Jafari S, et al. Acetaminophen use and the risk of asthma in children and adults: a systematic review and metaanalysis. Chest 2009;136:1316-23.

140. Kallen B, Finnstrom O, Nygren KG, et al. Maternal drug use during pregnancy and asthma risk among children. Pediatr Allergy Immunol 2013;24:28-32.

141. Stolevik SB, Nygaard UC, Namork E, et al. Prenatal exposure to polychlorinated biphenyls and dioxins from the maternal diet may be associated with immunosuppressive effects that persist into early childhood. Food Chem Toxicol 2013;51:165-72.

142. Spanier AJ, Kahn RS, Kunselman AR, et al. Prenatal exposure to bisphenol $A$ and child wheeze from birth to 3 years of age. Environ Health Perspect 2012;120:916-20.

143. Gascon M, Vrijheid M, Martinez D, et al. Pre-natal exposure to dichlorodiphenyldichloroethylene and infant lower respiratory tract infections and wheeze. Eur Respir J 2012;39:1188-96.

144. Li DK, Chen H, Odouli R. Maternal exposure to magnetic fields during pregnancy in relation to the risk of asthma in offspring. Arch Pediatr Adolesc Med 2011;165:945

145. Ege MJ, Mayer M, Normand AC, et al. Exposure to environmental microorganisms and childhood asthma. N Engl J Med 2011;364:701-9.

146. Braun-Fahrlander C, Riedler J, Herz U, et al. Environmental exposure to endotoxin and its relation to asthma in school-age children. N Engl J Med 2002;347:869-77.

147. Kull I, Wickman M, Lilja G, et al. Breast feeding and allergic diseases in infants-a prospective birth cohort study. Arch Dis Child 2002;87:478-1.

148. Kull I, Bergstrom A, Lilja G, et al. Fish consumption during the first year of life and development of allergic diseases during childhood. Allergy 2006;61:1009-15.

149. Medical Research Council. A framework for development and evaluation of RCTs for complex interventions to improve health. 2000. http://www.mrc.ac.uk/pdf-mrc_cpr.pdf 